\title{
Pengaruh Gaya Kepemimpinan dan Pengambilan Keputusan Terhadap Kinerja Pegawai dalam Organisasi Pemerintah Kelurahan
}

\author{
Mulyo Handono \\ Moelhanzdono42@gmail.com \\ Mahasiswa Fakultas Ekonomi dan Bisnis Universitas Narotama
}

\begin{abstract}
ABSTRAK
Tujuan dari studi ini adalah untuk mengetahui fungsi dan tujuan pengambilan keputusan dan mengetahui proses dan cara mengevaluasi kinerja pegawai. Dalam penelitian ini digunakan pendekatan kualitatif, dalam penelitian kualitatif, peneliti sekaligus berfungsi sebagai instrument utama yang terjun kelapangan serta berusaha sendiri mengumpulkan data melalui observasi maupun wawancara dan interview. Dalam penelitian ini digunakan metode induktif untuk menarik suatu kesimpulan terhadap hal-hal atau peristiwa-peristiwa dari data yang telah dikumpulkan melalui observasi, wawancara, dan dokumentasi, yang bisa digeneralisasikan (ditarik kearah kesimpulan umum), maka jelas metode induktif ini untuk menilai fakta-fakta empiris yang ditemukan lalu dicocokan dengan teori-teori yang ada. Pengambilan keputusan yang efektif dapat berpengaruh terhadap peningkatan kualitas kinerja perusahaan yang dalam implementasinya bisa melalui variabel perantara yaitu meningkatnya kinerja, semangat, kreativitas dari pegawai-pegawai yang dipimpinnya.
\end{abstract}

Kata Kunci ; Pengambilan Keputusan, Metode Induktif, kinerja karyawan

\section{PENDAHULUAN}

\subsection{Latar Belakang}

Pengambilan keputusan merupakan tindakan manajemen dalam mencapai sasaran. Teori pengambilan keputusan memiliki unsur-unsur utama berupa pembuat keputusan dihadapkan pada suatu masalah tertentu yang dapat diperbandingkan satu sama lain, Tujuan-tujuan, nilai-nilai atau sasaran yang mempedomani pembuat keputusan amat jelas dan dapat ditetapkan tingkatannya sesuai dengan urutan pentingnya. Berbagai alternatif untuk memecahkan masalah tersebut diteliti secara seksama. Akibatakibat yang ditimbulkan oleh setiap alternatif yang dipilih dengan teliti. Setiap alternatif dan masingmasing akibat yang menyertainya dapat dibandingkan dengan alternatifalternatif lainnya serta pembuat keputusan akan memilih alternatif dan akibat-akibatnya yang dapat memungkinkan tercapainya tujuan, nilai atau sasaran. Dengan banyaknya alternatif yang mempengaruhi sebuah keputusan maka sulit untuk mengambil sebuah keputusan secara manual.

\subsection{Perumusan Masalah}

1. Bagaimana Gaya Kepemimpinan yang diterapkan Lurah dalam pengambilan keputusan?

2. Faktor-faktor apa saja yang mempengaruhi penerapan Gaya Kepemimpinan Lurah dalam pengambilan keputusan?

3. Bagaimanakah kinerja pegawai pada Kelurahan Ciparigi?

4. Bagaimanakah pengaruh Gaya Kepemimpinan terhadap Kinerja Pegawai pada Kelurahan Ciparigi?

5. Bagaimanakah pelayanan Kelurahan yang diberikan kepada masyarakat? 


\subsection{Tujuan Penelitian}

1. Mengidentifikasi gaya kepemimpinan Lurah yang diterapkan dalam pengambilan keputusan.

2. Menelaah faktor-faktor yang mempengaruhi penerapan Gaya Kepemimpinan Lurah dalam pengambilan keputusan.

3. Menelaah kinerja pegawai pada organisasi Kelurahan Ciparigi serta pelayanan Kelurahan yang diberikan kepada masyarakat.

4. Menganalisis pengaruh Gaya Kepemimpinan terhadap Kinerja Pegawai pada Kelurahan Ciparigi.

\subsection{Kegunaan Penelitian}

Penelitian ini diharapkan dapat memberikan kegunaan kepada pihak-pihak terkait, seperti Kelurahan, Institusi pendidikan dan mahasiswa selaku peneliti. Bagi Kelurahan, hasil penelitian ini diharapkan dapat menjadi acuan untuk meningkatkan kinerja pegawai dan pemimpin dapat menerapkan gaya kepemimpinan pada pengambilan keputusan sesuai dengan kebutuhan pegawai dalam memperbaiki kinerja dan produktivitas pegawai, sehingga Kelurahan dapat meningkatkan pelayanannya terhadap masyarakat sebagaimana fungsi Kelurahan sebagai instansi pelayanan publik. Bagi pihak akademisi diharapkan penelitian ini dapat menjadi referensi bagi peneliti yang ingin mengkaji permasalahan Gaya Kepemimpinan terhadap Kinerja Pegawai secara lebih mendalam. Bagi peneliti sendiri, penelitian ini dapat berguna sebagai sarana belajar untuk memahami permasalahan yang menjadi topik kajian. 


\section{PENDEKATAN TEORITIS}

\subsection{Tinjauan Pustaka}

\subsubsection{Pengertian Dan Definisi Kepemimpinan}

Menurut Kerlinger dan Padhazur (1987), kepemimpinan adalah kemampuan tiap pimpinan di dalam mempengaruhi dan menggerakkan bawahannya sedemikian rupa sehingga para bawahannya bekerja dengan gairah, bersedia bekerjasama dan mempunyai disiplin tinggi, dimana para bawahan diikat dalam kelompok secara bersama-sama dan mendorong mereka ke suatu tujuan tertentu. Susilo (1998) menyatakan bahwa kepemimpinan merupakan keseluruhan aktivitas dalam rangka mempengaruhi orang-orang agar mau bekerjasama untuk mencapai suatu tujuan yang memang diinginkan bersama.

Perkataan pemimpin atau leader memiliki berbagai pengertian. Pemimpin merupakan dampak interaktif dari faktor individu atau pribadi dengan faktor situasi. Karjadi (1983) mendefinisikan pemimpin adalah orang yang mampu menggerakkan orang-orang lain agar orang-orang dalam suatu organisasi yang telah direncanakan dan disusun terlebih dahulu dalam suasana moralitas yang tinggi, dengan penuh semangat dan kegairahan dapat menyelesaikan pekerjaannya masing-masing dengan hasil yang diharapkan. Sedangkan menurut Wahjosumidjo (1984), kepemimpinan adalah proses antar hubungan atau interaksi antara pemimpin, bawahan dan situasi.

\subsubsection{Gaya Kepemimpinan}

Gaya kepemimpinan merupakan norma perilaku yang digunakan seseorang pada saat orang tersebut mencoba mempengaruhi orang lain seperti yang ia lihat (Thoha, 1993). Kebanyakan orang menganggap gaya kepemimpinan merupakan tipe kepemimpinan. Hal ini antara lain dinyatakan oleh Siagian (2003) bahwa gaya kepemimpinan seseorang adalah identik dengan tipe kepemimpinan orang yang bersangkutan.

Wahjosumidjo (1994) mengatakan bahwa perilaku pemimpin dalam proses pengambilan keputusan dan pemecahan masalah sesuai dengan gaya kepemimpinan seseorang. Gaya tersebut adalah sebagai berikut:

1. Gaya kepemimpinan Direktif adalah kemampuan mempengaruhi orang lain agar bersedia bekerja sama untuk mencapai tujuan yang telah ditentukan dengan cara segala kegiatan yang akan dilakukan diputuskan oleh pimpinan semata-mata.

2. Gaya kepemimpinan Konsultatif adalah kemampuan mempengaruhi orang lain agar bersedia bekerja sama untuk mencapai tujuan yang telah ditetapkan dengan cara berbagai kegiatan yang akan dilakukan oleh pemimpin setelah mendengarkan masukan/saran dari bawahan.

3. Gaya kepemimpinan Partisipatif adalah kemampuan mempengaruhi orang lain agar bersedia bekerja sama untuk mencapai tujuan yang telah ditetapkan dengan cara berbagai kegiatan yang akan dilakukan ditentukan bersama antara pimpinan dan bawahan.

4. Gaya kepemimpinan Delegatif adalah kemampuan mempengaruhi orang lain agar bersedia bekerja sama untuk mencapai tujuan yang telah ditetapkan dengan cara berbagai kegiatan yang akan dilakukan lebih banyak diserahkan kepada bawahan.

\subsubsection{Kinerja Pegawai}

Kinerja dapat diartikan sebagai gambaran mengenai tingkat pencapaian pelaksanaan suatu kegiatan atau program atau kebijakan dalam mewujudkan sasaran, tujuan, misi dan visi organisasi yang tertuang dalam rencana strategi suatu organisasi. Menurut Dessler (1997), kinerja merupakan prosedur yang meliputi (1) penetapan standar kinerja; (2) penilaian kinerja aktual pegawai dalam hubungan dengan standar-standar ini; (3) memberi umpan balik kepada pegawai dengan tujuan memotivasi orang tersebut untuk menghilangkan kemerosotan kinerja atau terus berkinerja lebih tinggi lagi.

Mengenai ukuran-ukuran kinerja pegawai, Ranupandojo dan Husnan (2000) menjelaskan secara rinci sejumlah aspek yang meliputi: 
1. Kualitas kerja adalah mutu hasil kerja yang didasarkan pada standar yang ditetapkan. Kualitas kerja diukur dengan indikator ketepatan, ketelitian, keterampilan dan keberhasilan kerja. Kualitas kerja meliputi ketepatan, ketelitian, kerapihan dan kebersihan hasil pekerjaan.

2. Kuantitas kerja yaitu banyaknya hasil kerja sesuai dengan waktu kerja yang ada, yang perlu diperhatikan bukan hasil rutin tetapi seberapa cepat pekerjaan dapat terselesaikan. Kuantitas kerja meliputi output, serta perlu diperhatikan pula tidak hanya output yang rutin saja, tetapi juga seberapa cepat dia dapat menyelesaikan pekerjaan yang ekstra.

3. Dapat tidaknya diandalkan termasuk dalam hal ini yaitu mengikuti instruksi, inisiatif, rajin, serta sikap hati-hati.

4. Sikap, yaitu sikap terhadap pegawai perusahaan dan pekerjaan serta kerjasama.

\subsubsection{Pelayanan Masyarakat}

Hakikat berdirinya suatu organisasi publik seperti Kelurahan adalah bertujuan melayani kepentingan masyarakat di wilayah kerjanya. Pelayanan yang diberikan oleh Kelurahan termasuk dalam bentuk pelayanan umum. Menurut Keputusan Menteri Negara Aparatur Negara No. 63 Tahun 2003, pelayanan umum adalah segala bentuk kegiatan pelayanan yang dilaksanakan oleh instansi pemerintah di pusat, di daerah, dan di lingkungan badan usaha milik negara/daerah dalam bentuk barang atau jasa dalam rangka pemenuhan kebutuhan masyarakat maupun dalam rangka pelaksanaan ketentuan peraturan perundang-undangan. Dari definisi pelayanan umum tersebut, dapat dikatakan bahwa Kelurahan merupakan suatu organisasi yang memberikan pelayanan kepada masyarakat dalam rangka pemenuhan kebutuhan masyarakat dan pelaksanaan ketentuan peraturan perundang-undangan sesuai dengan visi, misi, tujuan maupun program yang telah ditetapkan Kelurahan.

Parasuraman dkk (dalam Zeithamil dan Bitner, 1996) mengemukakan indikator- indikator pelayanan masyarakat sebagai berikut

1. Responsiveness atau responsivitas adalah kemampuan birokrasi untuk mengenali kebutuhan masyarakat, menyusun agenda dan prioritas pelayanan, serta mengembangkan programprogram pelayanan sesuai kebutuhan dan aspirasi masyarakat.

2. Reliability atau reabilitas adalah kemampuan organisasi untuk menyelenggarakan pelayanan yang dijanjikan secara akurat dan terpercaya.

3. Assurance atau kepastian adalah pengetahuan dan kesopanan para pekerja dan kemampuan mereka dalam memberikan kepercayaan kepada customers.

\subsubsection{Pengaruh Gaya Kepemimpinan Terhadap Kinerja Pegawai}

Gaya Kepemimpinan merupakan suatu cara yang dimiliki oleh seseorang dalam mempengaruhi sekelompok orang atau bawahan untuk bekerja sama dan berdaya upaya dengan penuh semangat dan keyakinan untuk mencapai tujuan yang telah ditetapkan. Keberhasilan suatu organisasi baik sebagai keseluruhan maupun berbagai kelompok dalam suatu organisasi tertentu, sangat tergantung pada efektivitas kepemimpinan yang terdapat dalam organisasi yang bersangkutan. Dapat dikatakan bahwa mutu kepemimpinan yang terdapat dalam suatu organisasi memainkan peranan yang sangat dominan dalam keberhasilan organisasi tersebut dalam menyelenggarakan berbagai kegiatannya terutama terlihat dalam kinerja para pegawainya (Siagian, 1999).

Pemimpin yang terdapat pada organisasi harus memiliki kelebihan-kelebihan dibandingkan dengan bawahannya, yaitu pegawai yang terdapat di organisasi yang bersangkutan, sehingga dapat menunjukkan kepada bawahannya untuk bergerak, bergiat, berdaya upaya yang tinggi untuk mencapai tujuan-tujuan yang telah ditetapkan. Akan tetapi hanya mengerahkan seluruh pegawai saja tidak cukup, sehingga perlu adanya suatu dorongan agar para pegawainya mempunyai minat yang besar terhadap pekerjaanya. Atas dasar inilah selama perhatian pemimpin diarahkan kepada bawahannya, maka kinerja pegawainya akan tinggi.

\subsection{Kerangka Pemikiran}

Berikut ini dikemukakan pendekatan yang digunakan dalam penelitian ini untuk memahami fenomena kepemimpinan pada organisasi pemerintahan Kelurahan, khususnya tentang pengaruh gaya 
kepemimpinan terhadap kinerja pegawainya. Terdapat berbagai faktor yang mempengaruhi gaya Kepemimpinan yang diterapkan seorang pemimpin dalam suatu organisasi. Faktor-faktor yang mempengaruhi gaya kepemimpinan yang diterapkan digolongkan dalam tiga kategori yaitu: faktor karakteristik pemimpin, faktor karakteristik pegawai dan faktor situasi. Gaya kepemimpinan yang digunakan seorang pemimpin memiliki pengaruh terhadap kinerja pegawai.

Untuk kepentingan penelitian ini, kinerja pegawai dipandang sebagai hasil kerja yang dapat dicapai seseorang atau sekelompok orang dalam suatu organisasi sesuai wewenang dan tanggung jawabnya untuk mencapai tujuan organisasi. Ukuran-ukuran kinerja pegawai ini meliputi kualitas kerja, dan kuantitas kerja.

Kinerja pegawai selain dipengaruhi oleh gaya kepemimpinan yang diterapkan oleh pemimpinnya (Lurah), juga dipengaruhi oleh karakteristik pegawai yang bersangkutan serta situasi yang terdapat pada lingkup organisasi. Kinerja pegawai akan berpengaruh terhadap Kinerja Organisasi pelayanan Kelurahan terhadap masyarakat. Alur pemikiran tersebut dapat dilihat pada Gambar 1.
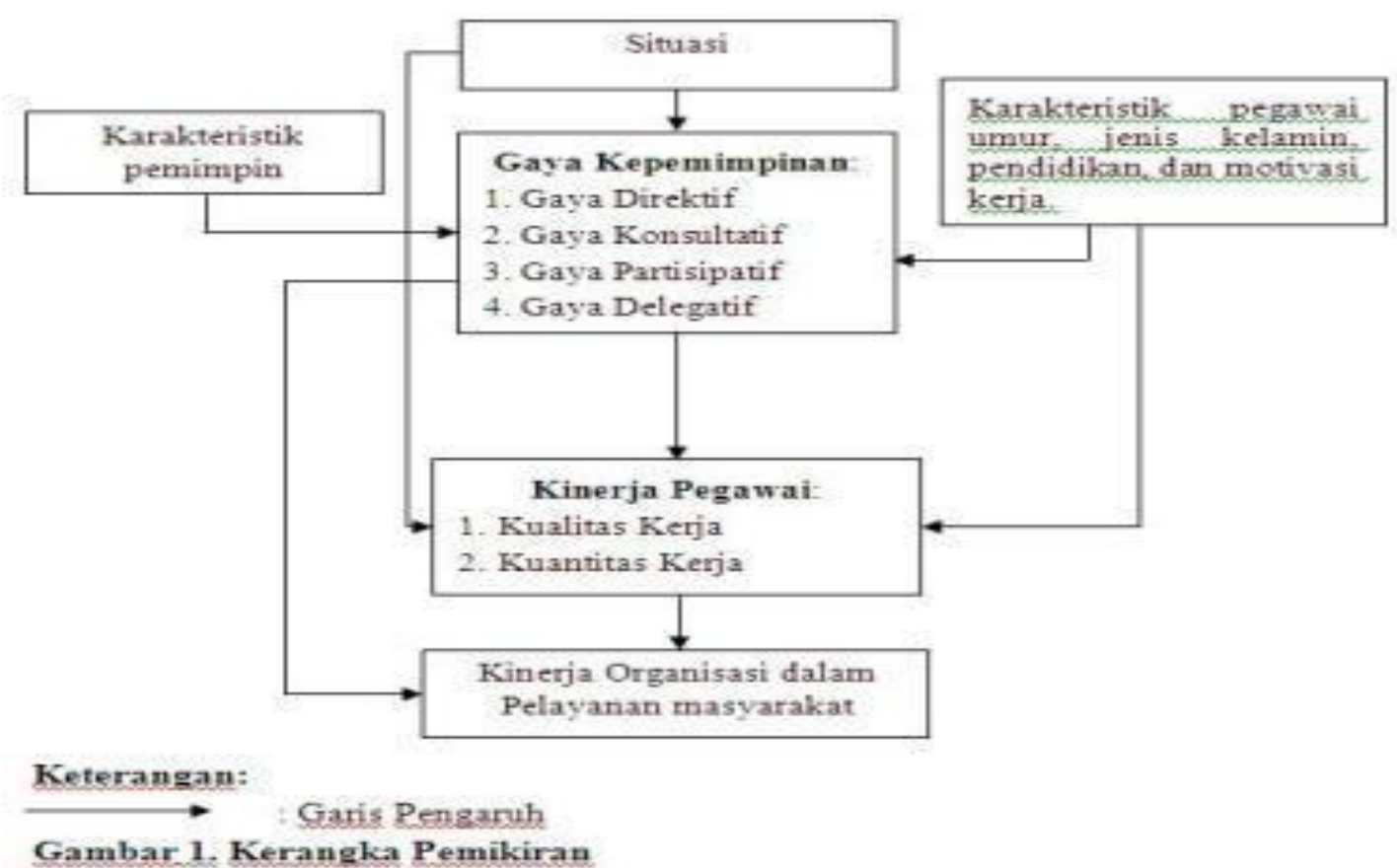

\section{PENDEKATAN LAPANGAN}

\subsection{Metode Penelitian}

Penelitian ini menggunakan kombinasi pendekatan kuantitatif (metode survei) dan pendekatan kualitatif. Metode survei adalah metode yang mengambil contoh data dari satu populasi dan menggunakan kuesioner sebagai alat pengumpulan data yang pokok (Singarimbun dan Effendi, 1989). Dengan memadukan kedua pendekatan tersebut diharapkan upaya pemahaman gaya kepemimpinan dalam pengambilan keputusan, faktor-faktor yang mempengaruhi gaya kepemimpinan dan pengaruhnya terhadap kinerja pegawai serta pelayanan Kelurahan terhadap masyarakat dapat dilakukan secara lebih komprehensif.

\subsection{Lokasi dan Waktu Penelitian}

Penelitian ini dilaksanakan di Kelurahan Ciparigi, Kecamatan Bogor Utara, Kota Bogor, Jawa Barat. Pemilihan lokasi penelitian dilakukan secara sengaja (purposive) dengan mempertimbangkan hal-hal berikut 
1. Berdasarkan hasil studi penjajakan pada bulan Maret 2009 diketahui bahwa Lurah Ciparigi telah menjabat lebih dari dua tahun sehingga diharapkan kepemimpinan yang telah dilaksanakannya dapat diteliti secara lebih mendalam.

2. Kelurahan Ciparigi merupakan juara pertama Lomba P2WKSS tingkat Propinsi.

Penelitian lapangan dilaksanakan pada bulan April sampai dengan Juni 2009.

\subsection{Teknik Pemilihan Responden dan Informan}

Dalam penelitian ini, teknik yang digunakan dalam menetapkan responden pegawai Kelurahan adalah total sampling, yaitu pengambilan sampel sebesar populasi yang ada. Hal ini mengacu pada pendapat Surakhmad (1989:14) bahwa adakalanya masalah penarikan sampel ditiadakan sama sekali dengan memasukkan seluruh populasi sebagai sampel, yakni semua jumlah populasi itu diketahui terbatas. Berdasarkan hasil studi penjajakan diketahui bahwa populasi seluruh pegawai Kelurahan Ciparigi berjumlah 12 orang. Informan dalam penelitian ini adalah seluruh pegawai Kelurahan Ciparigi dan Lurah Ciparigi. Disamping itu, untuk mengetahui kinerja pegawai Kelurahan dalam hal pelayanan Kelurahan terhadap masyarakat, populasi yang dijadikan sampel adalah warga masyarakat Kelurahan Ciparigi RT 02 dan 03 RW 05. Jumlah sampel yang dipilih adalah sebanyak 20 responden yang dipilih secara acak (simple random sampling).

\subsection{Teknik Pengumpulan Data}

Data yang akan dikumpulkan terdiri dari data primer dan data sekunder meliputi data kuantitatif dan data kualitatif. Data primer dikumpulkan dari para responden dan informan. Data primer yang dikumpulkan terdiri dari:

1. Gambaran Gaya Kepemimpinan pada Kantor Kelurahan Ciparigi yang digunakan pemimpin/Lurah dalam pengambilan keputusan.

2. Faktor-faktor yang mempengaruhi Gaya Kepemimpinan dalam mengambil keputusan.

3. Kinerja pegawai Kelurahan Ciparigi yang dilihat berdasarkan indikator kinerja pegawai serta pelayanan Kelurahan kepada masyarakat.

4. Pengaruh Gaya Kepemimpinan Lurah terhadap Kinerja Pegawai.

Data sekunder dikumpulkan dari Kantor Kelurahan Ciparigi, Dinas Instansi yang relevan dan perorangan, sesuai dengan keperluan data untuk penelitian ini. Data sekunder yang dikumpulkan terdiri dari:

1. Perda, kebijakan-kebijakan pemerintah mengenai kepegawaian terutama berkaitan dengan kepemimpinan Lurah dan kinerja pegawai.

2. Gambaran umum Kelurahan Ciparigi (kondisi geografis kelurahan, keadaan sosial demografi kelurahan, dan ketersediaan sarana dan prasarana penunjang kehidupan kelurahan).

\subsection{Teknik Pengolahan dan Analisis Data}

Data yang diperoleh dari kuesioner akan diolah secara kuantitatif. Data kuantitatif diolah dan disajikan dalam bentuk tabel frekuensi dan tabulasi silang. Tabulasi silang digunakan untuk mengetahui pengaruh gaya kepemimpinan terhadap kinerja pegawai. Pengolahan dan analisis data kualitatif dilakukan dengan mereduksi (meringkas) data dengan menggolongkan, mengarahkan, membuang yang tidak perlu dan mengorganisasikan data sedemikian rupa sehingga sesuai dengan keperluan untuk menjawab pertanyaan analisis di dalam penelitian. Data hasil wawancara yang relevan dengan fenomena yang dianalisis, disajikan dalam bentuk kutipan-kutipan. Analisis data kualitatif dipadukan dengan hasil interpretasi data kuantitatif. 


\section{DAFTAR PUSTAKA}

Alimudin, A., \& Sukoco, A. (2017). The Leadership Style Model That Builds Work Behavior Through Organizational Culture. JURNAL LENTERA: Kajian Keagamaan, Keilmuan Dan Teknologi, 3(2), 362-375.

Alimudin, A., \& Sasono, A. D. (2015). Peningkatan daya saing produk konveksi usaha kecil berbasis iptek di desa tri tunggal kecamatan babat lamongan. In Seminar Nasional Teknologi Terapan SV UGM.

Alimudin, A., \& Yoga, H. (2015). STRATEGI MENINGKATKAN LOYALITAS PELANGGAN PADA USAHA KECIL PRODUK MAKANAN RINGAN DI SURABAYA. Sustainable Competitive Advantage (SCA), 5(1)

Dessler. 1997. Manajemen Sumber Daya Manusia. Edisi Bahasa Indonesia Jilid 2. Jakarta: PT. Prenhallindo.

Ranupandojo, H, Suad Husnan. 2000. Manajemen Sumber Daya Manusia. Yogyakarta: BPFE-UGM.

Republik Indonesia, Peraturan Daerah Kota Bogor Nomor 13 Tahun 2008 tentang Organisasi Perangkat Daerah (Lembaran Daerah Kota Bogor Tahun 2008 Nomor 3 Seri D).

Siagian, Sondang P. 2006. Manajemen Sumber Daya Manusia. Jakarta: Penerbit Bumi Aksara.

Singarimbun, Masri dan Sofian Effendi. 1989. Metode Penelitian Survai. Jakarta:LP3ES.

Surakhmad, Winarno. 1989. Pengantar Penelitian Ilmiah Dasar. Bandung: Alumi.

Susilo, Martoyo. 1998. Manajemen Sumber Daya Manusia. Yogyakarta: BPFE-UGM.

Thoha, Miftah. 1993. Perilaku Organisasi: Konsep Dasar dan Aplikasinya. Jakarta: Rajawali Pers. Wahjosumidjo. 1984. Kepemimpinan dan Motivasi. Jakarta: Ghalia Indonesia. 
